\section{Obama swiftly reverses Bush orders}

US President Barack Obama began his first week in office with a series of executive orders, including one repealing a ban on US funding to international aid groups that perform or offer advice on abortions.

First instituted in 1984 by Ronald Reagan, the 'global gag rule' was repealed by Bill Clinton in 1993 and then reinstated by George W. Bush in 2001.

Although Obama has halted all pending rules and regulations, several controversial policies from the Bush administration's last days have already taken effect, including one that allows agencies to bypass federal wildlife biologists when reviewing projects under the Endangered Species Act.

And on 26 January, Obama announced plans to strengthen federal fuel-efficiency standards for vehicles and to review a decision by the Bush administration that would stop California and other states from adopting stricter standards of their own.

\section{Greenhouse-gas satellite heads into orbit}

Japan successfully launched its Greenhouse Gases Observing Satellite (GOSAT) on 23 January, to monitor levels of methane, water vapour, ozone and carbon dioxide. The Japan Aerospace Exploration Agency says that data from the satellite will provide details about the global distribution and seasonal variations of these gases, helping to refine climate-change predictions.

On 23 February, GOSAT will be joined by NASA's Orbiting Carbon Observatory, which will generate complementary data on the sources of carbon dioxide emissions (see Nature 450, 785-786; 2007).

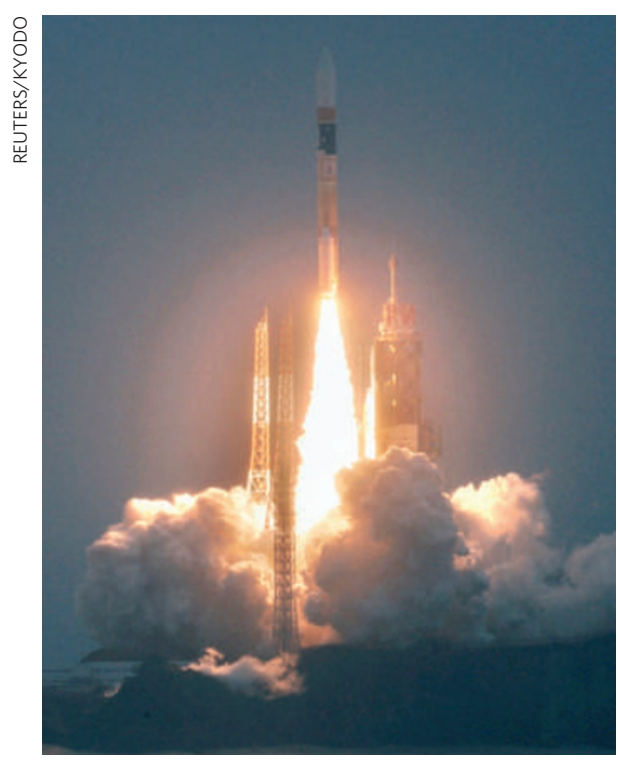

Japan's GOSAT heads for the heavens.

\title{
Tanzanian toad makes a colourful debut
}

The South Nguru Mountains in eastern Tanzania are home to this ornate toad (pictured), a still-unnamed member of the genus Nectophrynoides reported last month (M. Menegon et al. Acta Herpetologica 3, 107-127; 2008). It was among 15 amphibian species new to science that were discovered between 2004 and 2006 during surveys by a team led by Nisha Owen of the Frontier Tanzania Forest Research Program in Dar es Salaam.

The palm-sized toad's distinctive orange protuberances are glands, which may also be yellow and green or red. The glands' secretions are as yet unknown, but related amphibians exude noxious compounds to put off would-be predators.

\section{Pig farmer infected with Ebola virus}

Health officials in the Philippines confirmed last week that a worker at a pig farm has contracted the Ebola Reston subtype of Ebola virus.

The virus was found in pigs at two farms on Luzon, the largest island in the Philippines, last year (see Nature 457, $364-365 ; 2009$ ). Fifty workers at those farms were subsequently tested for antibodies to the virus, and one has tested positive. World Health Organization officials estimate that he contracted the virus between 6 and 18 months ago, although it has not been proved that he caught it from a pig.

Direct transmission from pigs to humans would be a cause for concern because pigs are thought to act as 'mixing vessels', where viruses can mutate into more virulent forms with a greater impact on human health.

\section{Europe's research activity lags behind its competitors'}

Investment in research and development (R\&D) in Europe is stagnating, according to reports from the European Commission.

The two reports, 2008 Innovation Scoreboard and 2008 Science, Technology and Competitiveness, reveal that Europe's research intensity - the percentage of gross domestic product (GDP) spent on $\mathrm{R} \& \mathrm{D}-$ languished at about $1.8 \%$ of GDP between 2000 and 2006. This leaves the European Union unlikely to reach the target of 3\% by 2010 set by European heads of state at a summit in Barcelona in 2002.

The reports single out poor $\mathrm{R} \& \mathrm{D}$ investment by business as a key problem, especially in France, Italy, the United
Kingdom and Germany, which together account for $69 \%$ of the European Union's R\&D spend.

Over the same period, R\&D intensity rose from $3.04 \%$ to $3.39 \%$ in Japan and from $0.90 \%$ to $1.42 \%$ in China; it fell from $2.74 \%$ to $2.61 \%$ in the United States.

For a longer version of this story, see http://tinyurl.com/d48sgj.

\section{US agencies under scrutiny over high-risk programmes}

A US congressional watchdog has added programmes at the Food and Drug Administration (FDA) and the Environmental Protection Agency (EPA) to its list of government operations that require special oversight or reform.

To help Congress set its agenda every two years, the Government Accountability Office identifies high-risk programmes that need to be either overhauled or guarded against "waste, fraud, abuse, and mismanagement". The report, released on 22 January, says that the FDA should, for instance, increase its inspections of foreign drug and medical-device manufacturers. The FDA plans to expand its oversight abroad, and has opened offices in China and India in the past six months.

The report also says that the EPA should speed up its evaluations of chemical risks and have the power to demand more safety information from chemical companies. 